Studia nad Autorytaryzmem i Totalitaryzmem 41, nr 4 Wrocław 2019

DOI: $10.19195 / 2300-7249.41 .4 .11$

\author{
MONIKA CZECHOWSKA \\ ORCID: 0000-0001-8070-6094 \\ Uniwersytet Wrocławski
}

\title{
Prawo karne w państwie totalitarnym - casus Korei Północnej
}

Korea Północna jest politycznym potworem, do którego - w skali świata - nie ma porównania [...] to zlepek nacjonalizmu, rasizmu, konserwatyzmu, stalinizmu, maoizmu - ideologiczna mieszanka wybuchowa, najbardziej totalitarne państwo w historii ${ }^{1}$.

\section{Wprowadzenie}

Trudno sobie wyobrazić, że w XXI wieku istnieje państwo, w którym za dowcip ${ }^{2}$, ziewnięcie podczas politycznego przemówienia ${ }^{3}$ czy też śpiewanie popowych piosenek ${ }^{4}$ grozi kara śmierci, a za przypadkowe zbicie popiersia wodza, położenie gazety z jego wizerunkiem na podłodze lub inne przejawy „nieposłuszeństwa" władzy z całą rodziną — aż do trzeciego pokolenia — trafia się do

${ }^{1}$ Wypowiedź W.J. Dziaka, kierownika Zakładu Azji i Pacyfiku oraz Centrum Badań Azji Wschodniej w ISP PAN w latach 2007-2017, a następnie kierownika Zakładu Bezpieczeństwa Globalnego i Studiów Strategicznych PAN w latach 2017-2019, fragment wywiadu dla „Rzeczpospolitej” — W Korei Pótnocnej dowcip równa się karze śmierci, https://www.rp.pl/artykul/1200839-WKorei-Polnocnej-dowcip-rowna-sie-karze-smierci.html (dostęp: 10.02.2019).

2 Ibidem.

3 BBC, North Korea defence chief Hyon Yong-chol ,, executed”, https://www.bbc.com/news/ world-asia-32716749 (dostęp: 10.02.2019).

${ }^{4}$ Informacja udzielona autorowi przez przewodnika podczas wizyty w Koreańskiej Strefie Zdemilitaryzowanej w kwietniu 2018 roku. 
obozu koncentracyjnego ${ }^{5}$. Tymczasem nie jest to tylko Orwellowska wizja świata, ale północnokoreańska rzeczywistość.

Realia praw człowieka w Korei Północnej — a raczej ich nieprzestrzegania — stały się znane światu za sprawą relacji uciekinierów ${ }^{6}$, niezależnych raportów sporządzonych przez międzynarodowe organizacje, takie jak ONZ ${ }^{7}$, Komitet Praw Człowieka w Korei Północnej ${ }^{8}$, Koreański Instytut Zjednoczenia Narodowego ${ }^{9}$ czy Amnesty International ${ }^{10}$ oraz prac badaczy (w szczególności profesora Waldemara Dziaka oraz doktora Nicolasa Levi ${ }^{11}$ ) zajmujących się tematyką północnokoreańską.

Obraz Korei Północnej wyłaniający się z wskazanych źródeł jest przerażający. Ostatni relikt stalinowskiej utopii jawi się jako gułag w sowieckim stylu, charakteryzujący się arbitralnym systemem sądowniczym, ekspansywną koncepcją

5 M. Bugno, Z wizyta na granicy piekła, https://wiadomosci.wp.pl/z-wizyta-na-granicy-piekla-6225941158762113a (dostęp: 16.02.2019).

6 Jednym z pierwszych świadectw była relacja wenezuelskiego poety i komunisty Alego Lamedy, który został zaproszony do Korei Północnej w 1966 roku, aby przełożyć prace Kim Ir Sena na język hiszpański. Po roku aresztowano go i skazano - w jednodniowym procesie - na 20 lat obozu, jako przyczynę skazania wskazując listy, jakie wysyłał w czasie pobytu do rodziny, oraz żart pod adresem Kim Ir Sena, który opowiedział podczas oficjalnego bankietu. W konsekwencji został oskarżony o szpiegowanie na rzecz CIA; w obozie spędził siedem lat. Uwolniono go dopiero 27 września 1974 roku dzięki interwencji Rumunii i Wenezueli. Był na granicy śmierci. Szerzej na ten temat zob. A. Bartuś, Korea Pótnocna - państwo totalitarne zagrażajace bezpieczeństwu globalnemu. Zarys problemu, „Chorzowskie Studia Polityczne” 2014, nr 7. Bezpieczeństwo i prawa człowieka. Analiza wybranych problemów globalnych, red. M. Ochwat, s. 60. Więcej zeznań świadków zob. D. Hawk, The Hidden Gulag - The Lives and Voices of ,, Those Who are Sent to the Mountains”. Exposing North Korea's Vast System of Lawless Imprisonment, Washington 2012, s. 48 n.

7 Mowa tutaj o raporcie z 2014 roku - UN Human Rights Council, Report of the detailed findings of the commission of inquiry on human rights in the Democratic People's Republic of Korea, UN Doc. A/HRC/25/CRP.1, http://www.ohchr.org/EN/HRBodies/HRC/CoIDPRK/Pages/ ReportoftheCommissionofInquiryDPRK.aspx (dostęp: 16.02.2019). Na marginesie należy dodać, że oenzetowska Komisja Praw Człowieka (UNCHR) w 2013 roku po raz pierwszy utworzyła trzyosobowy zespół dochodzeniowy do zbadania przestrzegania praw człowieka w Korei Północnej, $\mathrm{z}$ australijskim sędzią Michaelem Kirbym na czele.

${ }^{8}$ D. Hawk, op. cit.

9 Korea Institute for National Unification, White Paper on Human Rights in North Korea, Seul 2018, http://www.kinu.or.kr/pyxis-api/1/digital-files/d8ec7c10-a8fb-40ab-b8a7-a00065832e39 (dostęp: 16.02.2019).

${ }^{10}$ Amnesty International Global Report, Death sentences and executions, London 2017, https://amnesty.org.pl/wp-content/uploads/2018/04/Death-Penalty-REPORT-web-FINAL.pdf (dostęp: 30.01.2019).

11 W szczególności warto zapoznać się z publikacją autorstwa W. Dziaka, Korea Pólnocna. U źródet rodzinnej sukcesji władzy, Warszawa 2009; a także z pozycjami autorstwa N. Levi, The North Korean leadership and the future of North Korea, „Papers of the British Association of Korean Studies. British Association of Korean Studies” 2011; oraz idem, Kto rzadzi w Korei Pótnocnej?, Warszawa 2015; idem, Nic nie wiem o Korei Pótnocnej, Warszawa 2018. 
przestępczości i przerażającymi nadużyciami praw człowieka ${ }^{12}$. Ocenianie wartości ludzkiej przez pryzmat politycznej przydatności nie znajduje jednak wytłumaczenia ani w różnicach między zachodnim a konfucjańskim systemem wartości ${ }^{13}$, ani w północnokoreańskim dekalogu, na którym opiera się ideologia dżucze ${ }^{14}$.

Pojawia się wobec tego pytanie o to, jaki wpływ na takie przestrzeganie praw człowieka w Korei Północnej ma prawo, a w szczególności prawo karne. Jeśli bowiem przyjąć, za Juliuszem Makarewiczem, że „prawo karne jest jakby negatywem fotograficznym, malującym [...] stan cywilizacji, budowę społeczną, potrzeby i ideały danego społeczeństwa" ${ }^{15}$ (a zatem ma ścisły związek z ustrojem społeczno-politycznym, w którym funkcjonuje ${ }^{16}$ ), prawo karne w wypadku Koreańskiej Republiki Ludowo-Demokratycznej (dalej też: KRLD) należałoby uznać za narzędzie do osiągnięcia nieograniczonej kontroli nad wszystkimi przejawami życia.

Celem niniejszego artykułu jest analiza przepisów części ogólnej kodeksu karnego ${ }^{17}$ aktualnie obowiązującego w Koreańskiej Republice Ludowo-Demokratycznej, a w dalszej perspektywie znalezienie odpowiedzi na pytanie, czy prawo karne w wypadku KRLD jest instrumentem polityki państwa totalitarnego.

\section{Kodeks karny KRLD — krótka historia obowiązywania i obecny kształt}

Aktem prawnym będącym odpowiednikiem kodeksu karnego w Koreańskiej Republice Ludowo-Demokratycznej jest wielokrotnie rewidowana ustawa karna z $1950 \mathrm{roku}^{18}$. Najbardziej doniosłe zmiany, będące próbą osłabienia politycz-

12 S. Haggard, M. Noland, Repression and punishment in North Korea: Survey evidence of prision camp experiences, „Politics, Governance and Security Series. East-West Center Working Papers" 2009, nr 20, s. 1.

13 Więcej na temat wpływu konfucjanizmu na system praw człowieka zob. K. Przybyszewski, Prawa człowieka w kontekstach kulturowych, ,Pisma Filozoficzne” 116, 2010, s. 138 n.

14 Więcej na ten temat zob. G. Strnad, Kim jest człowiek w państwie Kimów - rozważania o prawach człowieka w Korei Pólnocnej, [w:] Od teorii do praktyki politycznej, red. M. Kołodziejczak, R. Rosicki, Poznań 2012, s. 396.

15 J. Makarewicz, Prawo karne - wykład porównawczy, Lwów-Warszawa 1924, s. 10-15.

16 A. Marek, System Prawa Karnego, t. 1. Zagadnienia ogólne, Warszawa 2010, s. 5.

17 Na ogół prawnokarnego instrumentarium w KRLD składa się — oprócz kodeksu karnego jako prawa materialnego i kodeksu postępowania karnego jako prawa proceduralnego - ustawa o kontroli bezpieczeństwa obywateli, ustawa o tajemnicach, ustawa o karach administracyjnych, ustawa o wykonywaniu orzeczeń sądowych oraz ustawa o nadzorze prokuratorskim; zob. H.M. Sub, North Korean legal system's characteristics and perception of law. Report on Human Rights in North Korea, Seul 2014, s. 53. Istnieją ponadto różne źródła, takie jak rozporządzenia i decyzje rządowe oraz bilateralne i multilateralne umowy międzynarodowe, zob. Office of Court Administration, North Korea's Criminal Law, Seul 2006, s. 20.

18 Szczegółowy wykaz zmian znajduje się w tabeli zamieszczonej w raporcie przygotowanym przez Koreański Instytut Zjednoczenia Narodowego; zob. Korea Institute for National Unification, op. cit., s. 47, 49-51. 
nych akcentów ${ }^{19}$, miały miejsce w latach 1974, 1987, 1995, 1999, 2004 i $2017^{20}$ i polegały między innymi na zmniejszeniu liczby przestępstw zagrożonych karą śmierci połączonej z konfiskatą mienia i zamianie sankcji na dożywotnią pracę. Niemniej jednak podstawowe ramy północnokoreańskiego kodeksu karnego de facto pozostały niezmienione przez ponad pół wieku ${ }^{21}$, a filozofia, zgodnie z którą prawo jest podporządkowane polityce, nadal dominuje w zmienionym kodeksie karnym. Wynika to z faktu, iż północnokoreański system prawny w dużej mierze opiera się na modelu radzieckim i jest skupiony na ochronie państwa, ideologii i partii, a nie na ochronie praw jednostkowych obywateli ${ }^{22}$.

Teoria prawa obowiązująca w Korei Północnej traktuje prawa jednostki jako warunkowe oraz przyznaje pierwszeństwo ochronie interesu państwowego, co oznacza prymat ochrony reżimu ${ }^{23}$. Taka koncepcja prawa jest skutkiem przyjęcia założenia - wyrażonego chociażby w art. 11 Konstytucji $\mathrm{KRLD}^{24}$ — zgodnie z którym najwyższym prawem w Koreańskiej Republice Ludowo-Demokratycznej jest nie prawo stanowione, ale wola przywódcy uzasadniana ideologią dżucze $(\text { Juche })^{25}$, opracowaną przez Wielkiego Ojca Narodu (Kim Ir Sena ${ }^{26}$ ) i Wielkiego Przywódcę (Kim Dzong Ila).

Również w samej definicji kodeksu karnego z łatwością można dostrzec elementy marksistowsko-leninowskiej doktryny prawa. Kodeks karny KRLD w oficjalnym słowniku określony jest bowiem jako ,zbiór przepisów mających na celu dokładne określenie, wykonanie (za pomocą różnych metod karania dostosowanych do podziału klasowego) oraz zapobieganie przestępstwom popełnianych przez wrogów klasowych"27.

19 I. Sup Han, The 2004 revision of criminal law in North Korea: A take-off?, „Santa Clara Journal of International Law" 5, 2006, nr 1, s. 133.

${ }^{20}$ Korea Institute for National Unification, op. cit., s. 15.

21 K. Cho, Korean criminal law: Moralist prima ratio for social control, „Journal of Korean Law" 1, 2001, nr 1, s. 77.

${ }^{22}$ K. Un-yong, A study of the legal system of North Korea, „Vantage Point. Seoul” 1, 1978, nr 4, s. 2 .

23 J. Song, R. Weatherley, The evolution of human rights thinking in North Korea, ,Journal of Communist Studies and Transitional Politics" 24, 2008, s. 272-296.

24 Artykuł ten stanowi, że Koreańska Republika Ludowo-Demokratyczna prowadzi wszelkie działania pod przywództwem Koreańskiej Partii Robotniczej.

25 H.M. Sub, op. cit., s. 48.

${ }^{26}$ Kim Ir Sen podczas przemówienia z 28 kwietnia 1958 roku powiedział, że: „Prawo jest ważną bronią do realizacji polityki narodowej. Prawa są wyrazem polityki, a więc są jej podporządkowane i nigdy nie można ich rozdzielić” — The Kim Il-sung Collections, t. 12, Pyongyang 1981, s. 221; jeśli nie podano inaczej, przeł. M.C. Kim Ir Sen twierdził również, że prawo nie może zapewnić wolności wrogim ustrojowi elementom, które sprzeciwiają się socjalizmowi lub nieczystym elementom działającym wbrew interesom ludu; szerzej zob. J. Song, Human Rights Discourse in North Korea: Post-Colonial, Marxist, and Confucian Perspectives, London 2011, s. 104.

27 Political Dictionary, Pyongyang 1973, s. 1249. 
Kodeks karny KRLD składa się z dziewięciu rozdziałów. Dwa pierwsze (regulujące podstawowe zasady prawa karnego, definicję przestępstwa, zasady odpowiedzialności karnej oraz katalog kar) stanowią część ogólną prawa karnego. Natomiast pozostałe siedem to część szczególna, z czego jedynie jeden został poświęcony przestępstwom skierowanym przeciwko życiu i własności obywateli ${ }^{28}$, podczas gdy pozostałe sześć rozdziałów części szczególnej odnosi się do przestępstw politycznych ${ }^{29}$. Daje się wobec tego zauważyć znaczną dysproporcję pomiędzy kryminalizacją czynów, które godzą w dobro prawne, takie jak zdrowie i życie ludzkie, ochrona własności prywatnej czy wolności osobistej, a ochroną szeroko rozumianego dobra i interesu społecznego.

\section{Zasady ogólne kodeksu karnego KRLD ${ }^{30}$}

Jak już wspomniano, na część ogólną kodeksu karnego składają się regulacje zawarte w rozdziale pierwszym i drugim. Rozdział pierwszy w art. 1-9 określa podstawowe zasady prawa karnego.

Artykuł 1 wskazuje cele tego aktu normatywnego. Stanowi bowiem, że prawo karne Koreańskiej Republiki Ludowo-Demokratycznej ma na celu obronę suwerenności państwa i systemu socjalistycznego przez ustanowienie systemu odpowiedzialności karnej za zbrodnie, zapewniając jednocześnie, że ludzie mogą prowadzić niezależne i twórcze życie.

Z kolei art. 2 określa zasady traktowania przestępców i nakłada na państwo dwie powinności wobec skazanych: pierwsza z nich dotyczy traktowania sprawców przestępstw zgodnie z zasadami przypisanymi klasie robotniczej, druga natomiast wyraża powinność stosowania najpierw sankcji prawnych kładących nacisk przede wszystkim na edukację społeczną.

Artykuł 3 wyraża zasadę prewencji, w myśl której państwo powinno dążyć do tego, aby wszyscy obywatele szanowali i ściśle przestrzegali prawo stanowione. Zasada ta obejmuje także obowiązek partycypowania obywateli $\mathrm{w}$ walce $\mathrm{z}$ przestępczością poprzez system samokrytyki (saenghwal chonghwa ${ }^{31}$ ), w ramach któ-

28 Mowa tutaj o rozdziale IX (ostatnim).

29 D.C.Chu, H. Sung, G.R. Newmann, Crime and Punishment around the World, t. 3. Asia and Pacific, Santa Barbara-Denver-Oxford 2010, s. 178.

$30 \mathrm{~W}$ celu dokonania analizy przepisów karnych obowiązujących w KRLD oparto się na wersji aktu prawnego opublikowanego przez Ministerstwo Sprawiedliwości KRLD przełożonej na język angielski na zlecenie Citizens' Alliance for North Korean Human Rights przez zespół naukowców z Graduate School of International Studies, Hankuk University of Foreign Studies w składzie: Sang Hyup Lee, Hyeong Su Park, Kyung Eun Ha, Markus Simpson Bell, Lilian Lee i Andrew Wolman. Jak jednak wskazuje Seong Bin (zob. idem, North Korea's Application of its Criminal Laws. Report on Human Rights in North Korea, Seul 2014, s. 66), istnieje możliwość, że urzędników północnokoreańskich obowiązuje inna niż oficjalna wersja kodeksu karnego stosowana w praktyce.

31 W literaturze anglojęzycznej zasadę tę określa się jako system of self-criticism. 
rego każdy Koreańczyk podczas grupowych spotkań, odbywających się zwykle raz w tygodniu, musi publicznie opowiedzieć o swojej — chociażby wyimaginowanej — nielojalności wobec ideologii. Obowiązek denuncjacji obejmuje również donoszenie na co najmniej dwie inne osoby ${ }^{32}$. Uchylenie się od tej praktyki jest odbierane jako nieposłuszeństwo wobec władzy i w konsekwencji prowadzi do uznania takiej osoby za wroga klasowego. Celem instytucji samokrytyki jest thumienie oporu wobec Najwyższego Przywódcy i Partii Pracy oraz skuteczne zapobieganie komunikacji w społeczeństwie, a w dalszej perspektywie udaremnienie ewentualnej rebelii skierowanej przeciwko reżimowi ${ }^{33}$.

$\mathrm{Z}$ instytucją autodenuncjacji wiąże się także zasada premiowania skruszonych sprawców przestępstw wyrażona w art. 4-5. Artykuł 4 reguluje sytuację skruszonych sprawców, którzy dopuścili się przestępstwa zdrady kraju. W myśl tego przepisu skruszony przestępca może zostać zwolniony z odpowiedzialności karnej, jeżeli podejmuje aktywne działania na rzecz KRLD. Artykuł 5 stanowi z kolei, że państwo powinno okazać wyrozumiałość i wybaczyć przestępcy, który dobrowolnie poddaje się odpowiedzialności.

Artykuł 6 wyraża zasadę nullum crimen sine lege. Zgodnie z tym przepisem państwo nakłada odpowiedzialność karną tylko za czyny określone jako przestępstwo przez ustawę. W świetle relacji zbiegów i na podstawie informacji zamieszczonych w niezależnych raportach opisujących skalę naruszeń praw człowieka wydaje się jednak, że przepis ten jest jedynie fasadowy. Tezę tę dodatkowo uzasadnia fakt, iż północnokoreański kodeks karny częstokroć używa pojęć niedookreślonych, co sprzyja nadmiernej kryminalizacji.

Następny artykuł formułuje zasadę stopniowania sankcji karnej w zależności od stopnia niebezpieczeństwa popełnionego przestępstwa i postawy sprawcy. Artykuł 8 reguluje z kolei zakres podmiotowy obowiązywania ustawy karnej i stanowi, że ma ona zastosowanie do obywateli KRLD, którzy popełnili przestępstwo zarówno na terytorium Korei Północnej, jak i poza nim. Ponadto północnokoreański kodeks karny ma również zastosowanie do cudzoziemców, którzy popełnią przestępstwo na terytorium KRLD, z wyjątkiem osób zwolnionych z odpowiedzialności na podstawie immunitetu ustalanego zgodnie z protokołem dyplomatycznym. Co istotne, w myśl art. 8 kodeksu karnego KRLD ma on też zastosowanie do cudzoziemców, którzy popełniają przestępstwo przeciwko Korei Północnej lub przeciwko jej obywatelom nawet w innym kraju. Ostatnim przepisem regulującym zasady ogólne prawa karnego jest art. 9, który ustanawia zasadę lex retro non agit.

Rozdział drugi określa zasady odpowiedzialności, definicję przestępstwa oraz wskazuje katalog kar funkcjonujących na gruncie północnokoreańskiego kodeksu karnego. W świetle kodeksu karnego KRLD — zgodnie z brzmieniem

32 R. Collins, Denied from the start - human rights at the local level in North Korea, https:// www.hrnk.org/uploads/pdfs/Collins_Denied_FINALFINALFINAL_WEB.pdf (dostęp: 16.02.2019).

${ }^{33}$ Ibidem. 
art. 10 - pod pojęciem przestępstwa rozumie się karalne, niebezpieczne działania, które naruszają suwerenność państwa, system socjalistyczny i przepisy państwowe, zarówno celowo, jak i w wyniku zaniedbania. Tym samym należy stwierdzić, że kodeks dopuszcza popełnienie przestępstw nie tylko poprzez działanie, lecz także zaniechanie.

Jeżeli zaś mowa o granicach wiekowych odpowiedzialności karnej to kwestia ta została uregulowana w art. 11 kodeksu karnego KRLD. W myśl tego przepisu odpowiedzialność karną nakłada się tylko na przestępców, którzy ukończyli 14. rok życia $\mathrm{w}$ momencie popełnienia przestępstwa. W tym miejscu podkreślenia wymaga, że zasada ta nie znajduje odzwierciedlenia w rzeczywistości. Jest to konsekwencja przyjęcia koncepcji odpowiedzialności za cudze czyny (yeon-jwa$-j e^{34}$ ), zgodnie z którą odpowiedzialność karną za przestępstwo popełnione przez członka rodzin ponosi cała rodzina - nie wyłączając dzieci — aż do trzeciego pokolenia ${ }^{35}$.

Kwestię niepoczytalności systematyzuje art. 12-13. Na mocy tych przepisów przewlekła choroba psychiczna lub czasowe zaburzenie psychiczne pozwalają na wyłączenie odpowiedzialności karnej i zastosowanie wobec sprawcy przestępstwa prewencyjnych środków natury medycznej. Wyłączenie odpowiedzialności nie dotyczy osób, które popełniły przestępstwo pod wpływem alkoholu. Artykuł 13 zawiera natomiast rozwiązanie swoiste dla prawa północnokoreańskiego, a mianowicie dopuszcza możliwość obciążenia osoby wcześniej niepoczytalnej odpowiedzialnością karną w wypadku powrotu przez nią do normalnego stanu psychicznego. Oznacza to więc możliwość odroczenia wykonania pierwotnej kary w terminie późniejszym, co godzi w zasadę pewności prawa.

Na uwagę zasługuje także regulacja $\mathrm{z}$ art. 15 wprowadzająca kontratyp obrony koniecznej. Zgodnie z brzmieniem tego przepisu czyn zdefiniowany jako przestępstwo popełniony w celu zapobieżenia przestępstwu przeciwko interesom państwa, interesom publicznym lub przeciwko legalnym interesom innych osób nie będzie karane, o ile było uzasadnione. Wobec tego uznać należy, że okolicznością wyłączającą bezprawność w takim stanie prawnym jest ochrona interesu państwa. Instytucja obrony koniecznej w północnokoreańskim wydaniu jest więc kolejnym przykładem na przyjęcie prymatu ochrony interesu aparatu państwowego, a nie obywateli.

Również odpowiedzialność karna za przestępstwa popełnione wobec członków rodziny została uregulowana w sposób osobniczy. Artykuł 18 stanowi bowiem, że przestępstwa popełnione wobec członka rodziny nie pociągają z sobą ex lege odpowiedzialności karnej — jeśli pokrzywdzony przestępstwem członek rodziny domaga się ułaskawienia, organ wyrokujący powinien uczynić zadość jego żądaniu, z wyjątkiem takich czynów, jak morderstwo, rabunek, gwałt i brutalny napad.

34 W literaturze anglojęzycznej zasadę tę określa się jako system of guilt-by-association.

35 R. Collins, A. Mortwedt Oh, From Cradle to Grave: The Path of North Korean Innocents, Washington 2017, s. 20-23. 
Także formy stadialne, takie jak przygotowanie i usiłowanie, zostały uregulowane w północnokoreańskim kodeksie karnym. Co ciekawe, przy ustalaniu wysokości kary w wypadku form stadialnych bierze się pod uwagę przyczyny niepowodzenia popełnienia przestępstwa.

Kodeks karny KRLD reguluje też instytucję podżegania i pomocnictwa ${ }^{36}$, z tym że podżegaczowi grozi kara jak za sprawstwo albo surowsza, a dla pomocnika kara taka jak za sprawstwo albo łagodniejsza. Osobnymi przestępstwami są natomiast: ukrywanie sprawcy przestępstwa lub dowodów na jego popełnienie ${ }^{37}$, niezgłoszenie planowanego lub dokonanego przestępstwa ${ }^{38}$ oraz niepodjęcie działań mających na celu zapobieżenie popełnianiu przestępstwa ${ }^{39}$.

\section{System kar}

System karny odgrywa kluczową rolę w represyjnej reakcji rządu na zmiany gospodarcze i społeczne, jest też narzędziem walki z wszelkimi przejawami, nawet wyimaginowanego, nieposłuszeństwa władzy. Kara w północnokoreańskim systemie jest nie tylko ujemną reakcją na popełnione przestępstwo, polegającą na zadaniu sprawcy osobistej dolegliwości w celu zadośćuczynienia społecznemu poczuciu sprawiedliwości, lecz także „ostrą bronią dyktatury proletariatu”, mającą na celu opanowanie elementów antyrewolucyjnych ${ }^{40}$. Innymi słowy, sankcja w KRLD jest środkiem do osiągnięcia celów wyznaczanych przez ideologię dżucze ${ }^{41}$.

Katalog kar został uregulowany w art. 27 kodeksu karnego KRLD. Zgodnie tym artykułem karami są:

1. kara śmierci,

2. kara dożywotniej pracy naprawczej połączona z izolacją,

3. kara terminowej pracy naprawczej połączona z izolacją,

4. kara pracy krótkoterminowej,

5. pozbawienie prawa do głosowania,

6. konfiskata mienia,

7. cofnięcie uprawnień,

8. zwieszenie uprawnień.

Kary wymienione w punktach 1-4 są karami głównymi, a pozostałe sankcje (wymienione w punktach 5-8) należy uznać za kary uzupełniające, wymierzane oprócz kary zasadniczej ${ }^{42}$.

\footnotetext{
36 Zob. art. 22 kodeksu karnego KRLD.

37 Zob. art. 24 kodeksu karnego KRLD.

38 Zob. art. 25 kodeksu karnego KRLD.

39 Zob. art. 26 kodeksu karnego KRLD.

40 K. Geun-sik, Criminology, Seul 1986, s. 155-157.

41 Ibidem.

42 Zob. art. 28 kodeksu karnego KRLD.
} 
Pierwszą w kolejności karą uregulowaną w kodeksie jest kara śmierci. Artykuł 29 oficjalnie zakazuje jej orzekania i wykonywania jedynie wobec osób, które w momencie popełnienia przestępstwa nie ukończyły 18 lat oraz wobec kobiet ciężarnych. W pozostałych przypadkach kara śmierci stanowi legalną i często używaną formę karania. Orzeczenie kary ostatecznej jest dopuszczalne w wypadku popełnienia wielu przestępstw, takich jak kradzież, morderstwo, gwałt, przemyt narkotyków, zdrada, szpiegostwo, dezercja, piractwo, konsumpcja mediów niezatwierdzonych przez rząd oraz posiadanie religijnych przekonań sprzecznych z praktykowaną ideologią dżucze ${ }^{43}$. Kara śmierci może ponadto zostać orzeczona wobec sprawcy, który w przeszłości popełnił już przestępstwo, oraz wobec sprawcy, który zdaniem organu nie wykazuje wyrzutów sumienia (gaejunseon$g)^{44}$. Oznacza to, że zasięg przestępstw, za które grozi kara śmierci, jest znacznie szerszy i oparty na uznaniowości organu orzekającego.

Koreańska Republika Ludowo-Demokratyczna nie udostępnia krajowych statystyk kryminalnych ani raportów na temat poziomu przestępczości, dlatego oszacowanie skali stosowania kary śmierci jest utrudnione ${ }^{45}$. Niemniej jednak w 2014 roku Rada Praw Człowieka ONZ utworzyła komisję śledczą do spraw praw człowieka w Koreańskiej Republice Ludowo-Demokratycznej, która ustaliła, że kara śmierci jest wykonywana systematycznie, w dodatku najczęściej przybiera formę rozstrzelania przez pluton egzekucyjny, powieszenia lub dekapitacji. Również z raportu Amnesty International bezsprzecznie wynika, że egzekucje w Korei Północnej są zjawiskiem powszechnym ${ }^{46}$ oraz nierzadko łączą się ze stosowaniem tortur ${ }^{47}$. Co istotne, jak można wnioskować $\mathrm{z}$ relacji dezerterów, orzeczenie kary śmierci jest zależne od przynależności klasowej. Jak wskazuje Pierre Rigoulot, przykładowo karę śmierci za gwałt orzeka się tylko w stosunku do obywateli należących do ,najniższych kategorii”, przez które rozumie się obszarników, kapitalistów, kolaborantów japońskich, kontrrewolucjonistów, uciekinierów i ich rodziny ${ }^{48}$.

Stosowanie kary śmierci ma pełnić przede wszystkim funkcję odstraszającą. Cel ten jest osiągany przez zmuszanie obywateli do udziału w publicznych egzekucjach. Warto w tym miejscu wskazać, że Korea Północna jest jednym

43 UN Human Rights Council, op. cit.

44 Korea Institute for National Unification, op. cit., s. 48.

45 Country Reports on Human Rights Practices for 2012, Korea, Democratic People's Republic of, Bureau of Democracy, Human Rights and Labor, U.S. Department of State, Washington 2013, https://www.state.gov/documents/organization/204420.pdf (dostęp: 10.01.2019).

46 Amnesty International, Torture, Execution Rampant in Vast N. Korea Prisons, London 2013.

47 Christian Solidarity Worldwide, North Korea: A Case to Answer - a Call to Act, New Malden 2007, s. 36-37.

48 P. Rigoulot, Korea Pótnocna, Wietnam, Laos - nasienie smoka, [w:] S. Courtois et al., Czarna księga komunizmu. Zbrodnie, terror, prześladowania, Warszawa 1999, s. 520. 
z czterech ostatnich krajów, które nadal wykonują je publicznie; pozostałe trzy to Iran, Arabia Saudyjska i Somalia ${ }^{49}$.

Kolejnymi karami wymienionymi w art. 27 północnokoreańskiego kodeksu karnego są kary pracy naprawczej: dożywotnia, terminowa i krótkoterminowa. Wszystkie łączą się z więzienną izolacją, a różnią jedynie okresem trwania. Kara pracy terminowej może trwać od roku do 15 lat $^{50}$, natomiast krótkoterminowa od sześciu miesięcy do dwóch lat ${ }^{51}$.

Kary polegające na tak zwanej pracy naprawczej (zarówno dożywotnia, terminowa, jak i krótkoterminowa) są odbywane w więzieniach i obozach stanowiących część systemu represji. Na marginesie należy wskazać, że pierwsze obozy pracy w Korei powstały w 1947 roku $^{52}$, różniły się jednak od współczesnych obozów, gdyż pobyt $\mathrm{w}$ nich wiązał się z konkretnym wyrokiem sądowym, a więźniowie mogli wówczas wychodzić na przepustki oraz kontaktować się z rodziną. Sytuacja zmieniła się po wojnie koreańskiej, kiedy to miejsca odosobnienia zamieniły się w obozy koncentracyjne wypełnione prawdziwymi i wyimaginowanymi wrogami reżimu ${ }^{53}$.

Opinia publiczna o istnieniu obozów oraz potwornych warunkach w nich panujących po raz pierwszy dowiedziała się za sprawą relacji wenezuelskiego poety i komunisty Alego Lamedy ${ }^{54}$. Obecnie ich istnienie jest bezsporne; świadczą o tym nie tylko relacje dezerterów i zdjęcia satelitarne, ale przede wszystkim fakt ten został potwierdzony we wrześniu 2014 roku przez północnokoreański rząd, który przyznał, że na terytorium KRLD istnieją obozy pracy, w których „ludzie pracują nad swoją mentalnością"55.

Na system więziennictwa składają się polityczne obozy pracy będące w rzeczywistości obozami koncentracyjnymi ${ }^{56}$ (kwan-li-so lub jeong-chi-beom $)^{57}$, reedukacyjne obozy pracy $(k y o-h w a-s o)^{58}$, obozy pracy naprawczej (ro-dong dan-żyeon-dae $)^{59}$, krótkoterminowe zakłady pracy karnej dla sprawców czynów

49 S. Rogers, M. Chalabi, Death penalty statistics, country by country, https://www.theguardian.com/news/datablog/2011/mar/29/death-penalty-countries-world (dostęp: 2.02.2019).

50 Zob. art. 30 kodeksu karnego KRLD.

51 Zob. art. 31 kodeksu karnego KRLD.

52 A. Bartuś, op. cit., s. 60.

53 P. Rigoulot, Analiza porównawcza obozów koncentracyjnych w nazistowskich Niemczech, Związu Radzieckim i Korei Pótnocnej, [w:] Korea Pótnocna za zastona, red. J. Hosaniak, A. Rzepliński, Warszawa 2004, s. 53.

54 A. Bartuś, op. cit.

55 The Guardian, North Korea admits using labour camps, https://www.theguardian.com/ world/2014/oct/08/north-korea-admits-using-labour-camps (dostęp: 20.02.2019).

56 P. Rigoulot, op. cit., s. 521-522.

57 D. Hawk, A. Mortwedt Oh, The Parallel Gulag: North Korea's „An-jeon-bu” Prison Camps, Washington 2017, https://www.hrnk.org/publications (dostęp: 2.02.2019).

58 Rada Praw Człowieka ONZ, Sprawozdanie z szczegółowych ustaleń komisji śledczej, Genewa 2014, s. 323-333.

59 Korea Institute for National Unification, op. cit., s. 89-90. 
o mniejszym ciężarze gatunkowym (jip-kyul-so ${ }^{60}$, ośrodki detencyjne (ku-ryu-jang $)^{61}$ oraz dlugoterminowe obozy pracy (kyo-yang-so $)^{62}$.

Spośród wskazanych ośrodków izolacji najbardziej rygorystyczne są obozy pracy przeznaczone dla więźniów politycznych ${ }^{63}$ oraz sprawców przestępstw o najcięższym ciężarze gatunkowym. Osadzeni często trafiają do nich bez podania przyczyny. Aresztowania „wrogów klasowych” nierzadko odbywają się w środku nocy, bez możliwości złożenia wyjaśnień oraz z pominięciem rzetelnego procesu sądowego ${ }^{64}$. Kwan-li-so przypominają nazistowskie obozy zagłady ${ }^{65}$. Znajduje to potwierdzenie w relacjach uciekinierów będących niegdyś strażnikami w obozach. Wspominają oni o ogrodzeniach z drutu kolczastego pod napięciem, psach specjalnie szkolonych do rozszarpywania ludzi, uzbrojonych strażnikach, polach minowych, racjach żywnościowych utrzymujących więźniów na granicy śmierci, katorżniczej pracy nawet po 16 godzin na dobę, torturach i przemocy seksualnej ${ }^{66}$. Polityczne obozy pracy lokalizowane są w górach, co zmniejsza szanse na ucieczkę. Obozy koncentracyjne zajmują powierzchnię porównywalną do wielkich miast - jak pisze Konrad Klonowski, największe z nich mają powierzchnię taką samą jak Seul ${ }^{67}$. Każdy obóz koncentracyjny dzieli się na dwie strefy: strefę absolutnej kontroli (są tam więźniowie, którzy nigdy nie wyjdą na wolność) i strefę „rewolucjonizującą”, z której więźniowie - niestety tylko teoretycznie — mogą zostać uwolnieni po przejściu reedukacji68.

Drugim elementem systemu więziennego są tak zwane reedukacyjne obozy pracy (kyo-hwa-so), w których odbywane są kary terminowe o łącznej długości trwania nieprzekraczającej 15 lat pozbawienia wolności ${ }^{69}$. Z kolei obozy pracy naprawczej (ro-dong dan-żyeon-dae) przeznaczone są dla sprawców przestępstw pospolitych, klasyfikowanych jako zachowania antyspołeczne i zagrożone karą od sześciu miesięcy do dwóch lat pracy ${ }^{70}$. Czwartym elementem składającym się na system represji są krótkoterminowe zakłady pracy karnej dla sprawców czynów o mniejszym ciężarze gatunkowym (jip-kyul-so) — ich celem ma być

${ }^{60}$ Korea Institute for National Unification, White Paper on Human Rights in North Korea, Seul 2018, s. 98.

61 D. Hawk, A. Mortwedt Oh, op. cit.

62 Ibidem.

63 N. Min, What kind of organization is North Korea's National Security Agency?, http://www. dailynk.com/english/read.php?cataId=nk00400\&num=2645 (dostęp: 5.02.2019).

64 P. Rigoulot, op. cit., s. 52.

65 Wypowiedź M. Kirby'ego zob. P. Walker, North Korea human rights abuses resemble those of the Nazis, says UN inquiry, https://www.theguardian.com/world/2014/feb/17/north-koreahuman-rights-abuses-united-nations (dostęp: 10.02.2019).

66 A. Bartuś, op. cit., s. 61.

${ }^{67}$ K. Klonowski, Pótnocnokoreańskie obozy podobne do radzieckich łagrów, https://pukhan. pl/2013/02/polnocnokoreanskie-obozy-podobne-do-radzieckich-lagrow (dostęp: 20.02.2019).

68 A. Bartuś, op. cit., s. 60.

69 S. Haggard, M. Noland, op. cit., s. 9.

70 Korea Institute for National Unification, White Paper..., 2009, s. 89-90. 
działanie wychowawcze ${ }^{71}$. Natomiast ośrodki detencyjne ( $k u$-ryu-jang) są czymś na kształt aresztów śledczych i służą do przeprowadzania dochodzeń w sprawie zatrzymanych podejrzanych ${ }^{72}$.

Wszystkie typy obozów składające się na północnokoreański system więzienny, niezależnie od nazwy i teoretycznych założeń, są miejscami, których istnienie w dzisiejszym świecie jest nie do przyjęcia ${ }^{73}$. Tymczasem obecnie w Koreańskiej Republice Ludowo-Demokratycznej tylko w obozach koncentracyjnych (kwan-li-so) przetrzymywanych jest około ćwierć miliona więźniów, niektórzy wchodzą tam, ważąc 75 kilogramów, a po dziesięciu miesiącach ich waga wynosi już tylko 35 kilogramów $^{74}$. Szacuje się, że w czasie blisko 70 lat rządów Kimów zmarło w nich około miliona osób ${ }^{75}$.

Oprócz kary śmierci i tak zwanej kary pracy (dożywotniej, długoterminowej i krótkoterminowej) kodeks karny KRLD ustanawia także kary dodatkowe, orzekane kumulatywnie obok kar zasadniczych. Mowa tutaj o sankcji polegającej na pozbawieniu biernego prawa wyborczego, konfiskacie mienia oraz cofnięciu lub zawieszeniu uprawnień.

Sankcja polegająca na pozbawieniu prawa głosu stosowana jest wobec sprawców, którzy popełnili zbrodnie przeciwko państwu i narodowi. Kara ta zgodnie z założeniami kodeksowymi - może być stosowana przez okres maksymalnie pięciu lat, $\mathrm{z}$ tym że bieg jej terminu rozpoczyna się dopiero po odbyciu kary zasadniczej.

Z kolei kara konfiskaty mienia polega na utracie prawa własności do mienia należącego do sprawcy przestępstwa na rzecz państwa. Nie ma przy tym znaczenia, czy mienie to stanowi współwłasność rodziny, z konfiskaty zwolnione są bowiem tylko: żywność, codzienne artykuły pierwszej potrzeby i pieniądze pozwalające rodzinie skazanego na egzystencję na minimalnym poziomie.

Ostatnimi sankcjami są kary pozbawienia i zawieszenia uprawnień. Kara pozbawienia kwalifikacji stosowana jest w szczególności w wypadku przestępstwa, w popełnieniu którego sprawca wykorzystał swoje umiejętności do umyślnego popełnienia aktu penalizowanego. Zawieszenie kwalifikacji jest orzekane na okres trzech lat, z tym że okres ten — podobnie jak w przypadku pozbawienia prawa głosu — rozpoczyna swój bieg dopiero z upływem kary zasadniczej.

Jeśli zaś idzie o wymiar kary, to w myśl kodeksu karnego KRLD powinien on zależeć od charakteru, motywów i celu przestępstwa, a także sposobu jego

71 Korea Institute for National Unification, White Paper..., 2018, s. 98.

72 Ibidem, s. 99.

73 Wypowiedź N. Heikin, reżyserki filmu Kimdżongilia. Kwiat Kim Dong Ila - Szokujacy dokument o Korei Pótnocnej w TVP Info, https://www.tvp.info/6122477/szokujacy-dokument-okorei-polnocnej-w-tvp-info (dostęp: 10.02.2019).

74 M. Bugno, op. cit.

75 D. Kubik, Korea Kimów, https://www.tvn24.pl/czarno-na-bialym,42,m/czarno-na-bialym-korea-kimow,552403.html (dostęp: 8.02.2019). 
popełnienia i konsekwencji zbrodni. Omawiany akt prawny stanowi co prawda, że granice kar przewidziane w odpowiednich artykułach ustawy należy traktować jako standard, ale jednocześnie przewiduje możliwość zaostrzenia wymiaru sankcji w sytuacjach, gdy sprawca jest głównym prowodyrem przestępstwa, recydywistą, popełnił je, będąc w zmowie lub w sposób brutalny, jak też przeciwko osobie, która jest pod jego opieką, lub też przy wykorzystaniu sposobności wystąpienia sytuacji wojennej lub katastrofy. Takie nieostre ujęcie okoliczności pozwalających na zaostrzenie kar de facto oznacza możliwość dowolnego ich kształtowania w zależności od uznania władzy, co w połączeniu z faktem, iż część szczególna kodeksu zawiera wiele absurdalnych wręcz uregulowań (na przykład przepis art. 196 penalizujący wybieranie „niewłaściwych”, to znaczy takich, którzy nie odnieśli sukcesu, sportowców na zawody sportowe), sprawia, że akt ten staje się bardzo groźnym narzędziem systemu totalitarnego.

\section{Konkluzja}

Historia zna liczne przypadki, gdy prawo karne tworzone było dla obrony systemu totalitarnego i miało być jednym z głównych środków służących osiąganiu celów politycznych, masowego naruszania praw człowieka i dokonywania zbrodni pod pozorem prawa, w tym zbrodni ludobójstwa ${ }^{76}$. Prawo karne praktykowane w Koreańskiej Republice Ludowo-Demokratycznej, będące jak dotąd najbardziej represyjnym prawem na świecie, również stanowi narzędzie reżimu, którego celem jest osiągnięcie nieograniczonej kontroli nad wszystkimi przejawami życia.

Prima facie mogłoby się wydawać, że ostatni relikt stalinowskiej utopii ostrożnie otwiera się na świat i — na skutek międzynarodowej presji — podejmuje kroki w celu dostosowania prawa (a w szczególności prawa karnego) do konwencyjnych standardów ${ }^{77}$. Jednakże jest to działanie stricte pozorowane, będące jedynie elementem dyplomatycznego ping-ponga pomiędzy organizacjami stojącymi na straży praw człowieka a Koreą Północną ${ }^{78}$. Najlepszym tego po-

76 Najlepszymi przykładami są chociażby nazistowska III Rzesza, komunistyczne ZSRR, faszystowskie Włochy czy khmerski nacjonalizm.

77 Koreańska Republika Ludowo-Demokratyczna jest członkiem ONZ od 1991 roku. Tym samym jest zobligowana do przestrzegania zarówno Powszechnej deklaracji praw człowieka, jak i Karty Narodów Zjednoczonych. Ponadto KRLD w 1981 roku przystąpiła do Międzynarodowego Paktu Praw Obywatelskich i Politycznych oraz Międzynarodowego Paktu Praw Gospodarczych, Społecznych i Kulturalnych. W 1990 roku przyjęła natomiast Konwencję o ochronie praw dziecka, a w 2001 roku Konwencję w sprawie likwidacji wszelkich form dyskryminacji kobiet. Wobec tego, na podstawie art. 26 Konwencji wiedeńskiej o prawie traktatów, KRLD jest związana postanowieniami międzynarodowych umów i w konsekwencji powinna dostosować prawo wewnętrzne do standardów wynikających z multilateralnych postanowień.

78 J. Toman, Human Rights in North Korea, http://nkhumanrights.or.kr/NKHR_new/index eng_new.htm (dostęp: 10.01.2019). 
twierdzeniem jest dyferencja między stanem prawnym de iure a stanem prawnym de facto $^{79}$ oraz uczynienie z prawa karnego prima, a nie ultima ratio.

W konkluzji należy stwierdzić, iż w wypadku Koreańskiej Republiki Ludowo-Demokratycznej trudno w ogóle mówić o prawie karnym we właściwym tego słowa znaczeniu, jako o normach, które służą ochronie dóbr i interesów społeczeństwa oraz poszczególnych jednostek. Dlatego też przepisy, na podstawie których dokonuje się naruszeń praw człowieka, należy traktować nie jako stosowanie prawa karnego, lecz jego nadużycie ${ }^{80} \mathrm{w}$ myśl zasady lex iniusta non est lex.

\section{Bibliografia}

\section{Opracowania}

Bartuś A., Korea Pólnocna - państwo totalitarne zagrażajace bezpieczeństwu globalnemu. Zarys problemu, „Chorzowskie Studia Polityczne” 2014, nr 7. Bezpieczeństwo i prawa człowieka. Analiza wybranych problemów globalnych, red. M. Ochwat.

Cho K., Korean criminal law: Moralist prima ratio for social control, „Journal of Korean Law” 1, 2001, nr 1.

Chu D.C., Sung H., Newmann G.R., Crime and Punishment around the World, t. 3. Asia and Pacific, Santa Barbara-Denver-Oxford 2010.

Collins R., Denied from the start - Human Rights at the Local Level in North Korea, Washington 2018.

Collins R., Mortwedt Oh A., From Cradle to Grave: The Path of North Korean Innocents, Washington 2017.

Cyprian T., Sawicki J., Materiały norymberskie, Warszawa 1948.

Dziak W., Korea Pólnocna. U źródet rodzinnej sukcesji władzy, Warszawa 2009.

Geun-sik K., Criminology, Seul 1986.

Haggard S., Noland M., Repression and punishment in North Korea: Survey evidence of prision camp experiences, „Politics, Governance and Security Series. East-West Center Working Papers" 2009, nr 20.

Hawk D., The Hidden Gulag - The Lives and Voices of ,"Those Who are Sent to the Mountains”. Exposing North Korea's Vast System of Lawless Imprisonment, Washington 2012.

Hawk D., Mortwedt Oh A., The Parallel Gulag: North Korea's „,An-jeon-bu” Prison Camps, Washington 2017.

Levi N., Kto rządzi w Korei Pótnocnej?, Warszawa 2015.

Levi N., Nic nie wiem o Korei Pótnocnej, Warszawa 2018.

79 Jednocześnie Korea Północna jest jednym z najbardziej represyjnych państw na świecie, gdzie rząd ogranicza wszelkie swobody obywatelskie i polityczne, w tym wolność wypowiedzi, zgromadzeń, stowarzyszeń i religii, a także zabrania wszelkiej zorganizowanej opozycji politycznej, niezależnych mediów, społeczeństwa obywatelskiego czy związków zawodowych. Ponadto, aby utrzymać lęk i kontrolę, rutynowo stosuje arbitralne aresztowania, tortury, pracę przymusową i publiczne egzekucje.

80 Dał temu wyraz wyrok Trybunału Norymberskiego z 30 września-1 października 1946 roku, osądzający głównych zbrodniarzy nazistowskich, a także późniejsze wyroki trybunałów międzynarodowych, osądzające zbrodnie przeciwko ludzkości i podstawowym prawom człowieka. 
Levi N., The North Korean Leadership and the Future of North Korea, ,, Papers of the British Association of Korean Studies. British Association of Korean Studies” 2011.

Makarewicz J., Prawo karne - wykład porównawczy, Lwów-Warszawa 1924.

Marek A., System Prawa Karnego, t. 1. Zagadnienia ogólne, Warszawa 2010.

Political Dictionary, Pyongyang 1973.

Przybyszewski K., Prawa człowieka w kontekstach kulturowych, „Pisma Filozoficzne” 116, 2010.

Rigoulot P., Analiza porównawcza obozów koncentracyjnych w nazistowskich Niemczech, Zwiazku Radzieckim i Korei Pólnocnej, [w:] Korea Pólnocna za zastona, red. J. Hosaniak, A. Rzepliński, Warszawa 2004.

Rigoulot P., Korea Pólnocna, Wietnam, Laos - nasienie smoka, [w:] S. Courtois, N. Werth, J.L. Panne, A. Paczkowski, K. Bartosek, J.L.Margolin, Czarna księga komunizmu. Zbrodnie, terror, prześladowania, Warszawa 1999.

Seong B., North Korea's Application of its Criminal Laws. Report on Human Rights in North Korea, Seul 2014.

Song J., Human Rights Discourse in North Korea: Post-Colonial, Marxist, and Confucian Perspectives, London 2011.

Song J., Weatherley R., The evolution of human rights thinking in North Korea, „Journal of Communist Studies and Transitional Politics" 24, 2008.

Strnad G., Kim jest człowiek w państwie Kimów - rozważania o prawach człowieka w Korei Pótnocnej, [w:] Od teorii do praktyki politycznej, red. M. Kołodziejczak, R. Rosicki, Poznań 2012.

Sub H.M., North Korean Legal System's Characteristics and Perception of law. Report on Human Rights in North Korea, Seul 2014.

Sup Han I., The 2004 revision of criminal law in North Korea: A take-off?, „Santa Clara Journal of International Law" 5, 2006, nr 1.

Un-yong K., A study of the legal system of North Korea, „Vantage Point. Seoul” 1, 1978, nr 4.

\section{Teksty publicystyczne}

BBC, North Korea defence chief Hyon Yong-chol ,executed”, https://www.bbc.com/news/worldasia 32716749.

Bugno M., Z wizyta na granicy piekta, https://wiadomosci.wp.pl/z-wizyta-na-granicy-piekla6225941158762113a.

The Guardian, North Korea admits using labour camps, https://www.theguardian.com/world/2014/ oct/08/north-korea-admits-using-labour-camps.

Klonowski K., Pólnocnokoreańskie obozy podobne do radzieckich łagrów, https://pukhan.pl/2013/02/ polnocnokoreanskie-obozy-podobne-do-radzieckich-lagrow.

Kubik D., Korea Kimów, https://www.tvn24.pl/czarno-na-bialym,42,m/czarno-na-bialym-korea-kimow,552403.html.

Min N., What kind of organization is North Korea's National Security Agency?, http://www.dailynk. com/english/read.php?cataId=nk00400\&num $=2645$.

Rzeczpospolita, W Korei Północnej dowcip równa się karze śmierci, https://www.rp.pl/artykul/1200839W-Korei-Polnocnej-dowcip-rowna-sie-karzesmierci.html.

Rogers S., Chalabi M., Death penalty statistics, country by country, https://www.theguardian.com/ news/datablog/2011/mar/29/death-penalty-countries-world.

Toman J., Human Rights in North Korea, http://nkhumanrights.or.kr/NKHR_new/index_eng_new.htm.

TVP Info, Szokujący dokument o Korei Pólnocnej w TVP Info, https://www.tvp.info/6122477/szokujacy-dokument-o-korei-polnocnej-w-tvp-info.

Walker P., North Korea human rights abuses resemble those of the Nazis, says UN inquiry, https:// www.theguardian.com/world/2014/feb/17/north-korea-human-rights-abuses-united-nations.

Studia nad Autorytaryzmem i Totalitaryzmem 41, nr 4, 2019

(C) for this edition by CNS 


\section{Orzecznictwo}

Wyrok Trybunału Norymberskiego z 30 września-1 października 1946 roku.

\section{Raporty}

Amnesty International Global Report, Death sentences and executions, London 2017.

Amnesty International, Torture, Execution Rampant in Vast N. Korea Prisons, London 2013.

Christian Solidarity Worldwide, North Korea: A Case to Answer - a Call to Act, New Malden 2007.

Country Reports on Human Rights Practices for 2012, Korea, Democratic People's Republic of,

Bureau of Democracy, Human Rights and Labor, U.S. Department of State, Washington 2013.

Korea Institute for National Unification, White Paper on Human Rights in North Korea, Seul 2009.

Korea Institute for National Unification, White Paper on Human Rights in North Korea, Seul 2018.

Office of Court Administration, North Korea's Criminal Law, Seul 2006.

Rada Praw Człowieka ONZ, Sprawozdanie z szczegółowych ustaleń komisji śledczej, Genewa 2014.

UN Human Rights Council, Report of the Detailed Findings of the Commission of Inquiry on Human Rights in the Democratic People's Republic of Korea, UN Doc. A/HRC/25/CRP.1, Genewa 2014.

\section{Inne}

The Kim Il-sung Collections, t. 12, Pyongyang 1981.

\section{CRIMINAL LAW IN A TOTALITARIAN STATE — A NORTH KOREAN CASE STUDY}

\section{Summary}

It is hard to imagine that in the 21 st century there is a state in which a joke, a yawn during a political speech or singing pop songs is punishable by death, and for accidentally breaking the bust of the chief, putting newspaper with his image on the floor or other manifestations of "disobedience" one can be sent to a concentration camp with one's whole family - three generations back. Meanwhile, it is not just an Orwellian vision of the world, but the North Korean reality.

This article aims to analyze the North Korean penal code and, consequently, to find the answer to the question of whether criminal law in the Democratic People's Republic of Korea is an instrument of a totalitarian state policy and, if so, of what kind.

Keywords: criminal law, totalitarianism, North Korea, Juche ideology, capital punishment, labour camps, executions by firing squad.

Monika Czechowska

monika.czechowska@uwr.edu.pl 